\title{
Tourist traffic in the Forest Arboretum of Warmia and Mazury in Kudypy
}

\author{
Adriana Auguścik \\ University of Warmia and Mazury in Olsztyn, Faculty of Economic Sciences, Institute of Economy and Finance, Department of Finance, \\ ul. Michała Oczapowskiego 4, 10-719 Olsztyn, Poland \\ Tel. +48 511096272, e-mail: adriana.auguscik@uwm.edu.pl
}

\begin{abstract}
One possible way to improve the health and well-being of people, especially those living in large urban agglomerations, is to provide the opportunity to spend time in the forest, which helps rest and regeneration by enabling contact with nature. Forest areas managed by the State Forests are therefore publicly available to tourists for recreational and educational purposes. A good example illustrating the scope of access to the forest and its resources, and the same time indicative of the degree of interest in forest tourism, is the Polish Forest Society's Forest Arboretum of Warmia and Mazury, run by the Kudypy Forest District in the Regional Directorate State Forests in Olsztyn.

The purpose of this work was to study the attendance of people visiting the Arboretum in 2014-2018 taking the variability of interest in visiting the Arboretum depending on the season of the year and the age of tourists (adults vs. children) into account. In overall, children were observed to visit the Arboretum more often than adults, while the largest number of organized groups visited the Arboretum in 2014. The most popular month among both, children and adults, was May. Using a Student's t-test, Pearson's Chi-squared test and Cramer's coefficient a significant relationship between adults and children visiting the Arboretum and the seasons was identified. Significant differences between the average number of visitors to the Arboretum among children and adults at a specific time of year was also observed.
\end{abstract}

Keywords: Forest tourism and recreation, sightseeing tourism, educational tourism, social functions of forests, Kudypy Forest District

\section{Introduction}

Forests and forest management have a number of functions in three balanced groups. First one of them are economic functions (production), that rely on production - based oncontinuity and renewability - both of basic raw material,that is wood, but also minor forest products for instance ground cover and game. Another group are protective functions (ecological) based for instance on soil, water, and landscape protection, or based on shaping the climate, both in local and global context. Third group are social functions, for many reasons as important as previous groups. They are connected with creating conditions for rest and recreation in forest or creating workplaces and conditions for ecological education (Milewski2017). Conducted by the State Forests (SF) permanently sustainable forest management is intended to evenly develop all functions of forest to meet and reconcile expectations of different social groups, and also to provide safety of nature.

According to the Organization for Economic Co-operation and Development, Polish population is at the top of the most overworked. In terms of overwork in 2017 it was placed on $10^{\text {th }}$ position in the world (OECD 2017). Long-term exposition to various stress factors in the environment will result in lowering the effectiveness of employees and may lead to health disorders. For proper functioning and maintaining good health, right rest and recreation is therefore necessary (Żywczok 2015).Limited time for rest determines possibilities and places for rest to the nearest surrounding of one's place of living, which is visible especially in the case of large urban agglomerations. Presence

Received: 23.10 .2019 r., accepted after revision: $11.02 .2020 \mathrm{r}$. 
of green area in the form of parks and gardens favours psychic relief and organism regeneration (Chojecka 2014). The importance of tourism run on forest areas is increasing, defined as silvitourism (Muszyński, Kozioł 2013).

The State Forests run many actions within tourism and forest education. Realization of social functions of forests may limit, to some extent, the production functions, but allows to meet social expectations. Social use of forest areas is a very important aspect, especially in forest complexes situated near large cities, and health recreation facilities of a different kind, where exploration of forest is intensified (Janusz, Pochopień 2012).

For Olsztyn and its surroundings' inhabitants, a perfect rest and recreation role playsPolish Forest Society's Forest Arboretum of Warmia and Mazury, run by the Kudypy Forest District, created thanks to foresters' initiative and localized in direct neighbourhood of town. Increasing number of visitors reflect the big interest and needs of local community.

Kudypy botanical garden has several important functions for society. First one of them is environment and forest education addressed to different age groups. Thanks to educational infrastructure, it is possible to expand knowledge not only in terms of forest but also historical subject matter. It is a place important to the region in terms of rest and recreation in combination with environmental education. Arboretum, available for visitors from April $15^{\text {th }}$ to October $31^{\text {st }}$ is fully adopted to the needs of disabled persons (Tumiłowicz et al. 2012; Auguścik 2017).

The aim of research was to study the frequency of visitors to the Arboretum in Kudypy in years 2014-2018 at different times of year, with division to age groups, as a reflection of society's interest in rest and recreation properly adopted for this role in forest environment.

\section{Methodology and research object}

For analysis, monographic method (Apanowicz 2002) was used, which uses the data on frequency (number of sold tickets to the Arboretum) obtained from Kudypy Forest District. The number of respondents was analysed during the functioning of the Arboretum - from April to October in the years 2014 2018. For frequency evaluation, groups were distinguished in terms of age categories (children and adults), according to the data obtained from forest district. Data was grouped into three periods, which covered different phases of evaluated forests' development (spring - W, summer - L, Autumn - J), and at the same time, reflected different periods of school/ professional activity (school $-\mathrm{W}$, vacation $-\mathrm{L}$, school $-\mathrm{J}$ ). Data illustratingthe number of visitors to the Arboretum was compared with $t$-Student test and chi-square independence test (Pearson). Cramer's Coefficient was also used. Test inve- stigates the dependence between number of children and adult visitors to the Arboretum and seasons(Zeliaś et al. 2002).

Polish Forest Society's Forest Arboretum of Warmia and Mazury in Kudypy is located around $8 \mathrm{~km}$ to the west from the centre of Olsztyn and around $400 \mathrm{~m}$ to the north from the headquarters of Kudypy Forest District, near national road number 16 from Olsztyn to Ostróda (Fig. 1). It is localized in forest stands of Kudypy Forest District and is convenient to commute to by city bus. A large car parking is located next to the Arboretum building, which also plays a role of Forest Education Centre (OEL) named 'Kudypska Polana'[Kudypy Clearing]. In OEL, didactic and conference room is located that is able to hold 40 people. There isalso a small museum of forestry with exhibition hall, in which the exposition of nature subject matteris presented. Forest Arboretum of Warmia and Mazury is the only facility of this type in North-West Poland and one of few in the whole country. It is located at an altitude of 136 meters above sea level. Found there can be dendrological specimen, bush composition and flower collections of forest plants.

A place in which today's botanical garden is located, until 1983 was a permanent seed stand (WND). However, in this period, hurricane winds damaged many trees growing there. Additionally, after this incident, the lowering of ground water took place, and the occurrence of secondary invaders. As an effect of these factors, forest growing in this place stopped being a permanent seed stand. In 1989, a decision was made to create a small Arboretum on this area.

Arboretum is undoubted a tourist attraction for the visitors. In 1990, a division of this place into two basic plants' sections was done: Polish flora and Collection of trees and bushes of foreign origin. In 1992,the first plantings were made, and in 1999, the Arboretum was accepted into the Council of Botanical Gardens in Poland (Hołdyński et al.

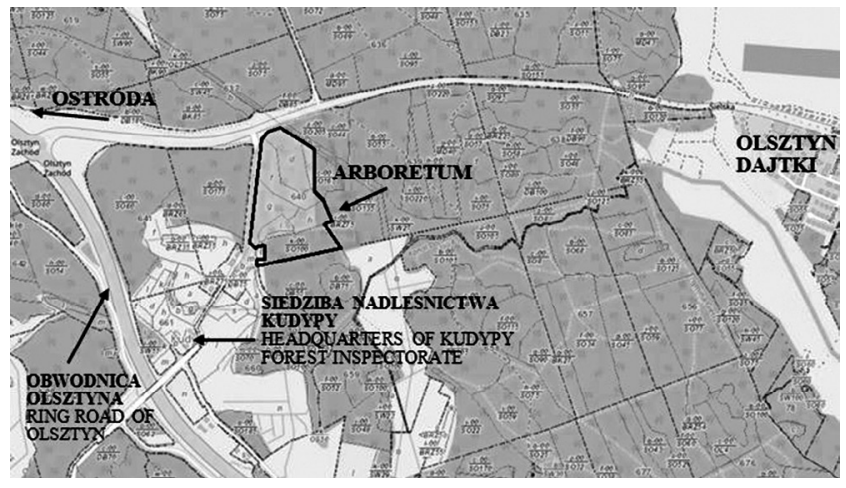

Figure 1. Location of the Polish Forest Society Forest Arboretum of Warmia and Mazury in Kudypy

Source: own elaboration based on https://www.bdl.lasy.gov.pl/portal/mapy [22.01.2020] 
1999). Since 2004, the Arboretum is reported to Botanical Gardens Conservation International (BGCI), which deals with plant protection (Tumiłowicz et al. 2012).

Initially, the garden was located on 7.54 ha area, which in 2012 was increased to $15.69 \mathrm{ha}$. On this area, we can find a collection of around 1.000 species and varieties of different trees and bushes from Poland, but also from all over the world. Additionally,there is a small Geological Lapidary Museum which is a collection of stones. Every year, the Arboretum develops and enrichens in new plantings, educational and tourist infrastructure (Kuszewska, Rutkowska 2018). Beside dendrological collection, visitors may learn about fungi, mosses and ferns specimen, occurring both in natural forms and introduced on purpose, in order to present the widest possible and interesting flora exhibition.

Arboretum in 2019 had a $30^{\text {th }}$ anniversary of existence. This year, touristic and recreational offer was enriched in three new thematic corners. Thanks to 'beekeeper corner' the visitors may learn many facts on bees and the work of a beekeeper. In 'relax corner', guest may relax by using equipment specially prepared for this purpose. A perfect place to meet on a date is in 'lovers corner'. It is very often visited by married couples for wedding photo shoots. Educational offer of Arboretum is also enriched by 'historical corner' that presents events that took place in the area under management of Kudypy Forest District.

\section{Research results}

\subsection{Characteristics of visitors' frequency}

Data presenting tourist traffic in the Arboretum is very variable, which refers also to age category of visitors and period of their stay and particular years of Arboretum functioning.

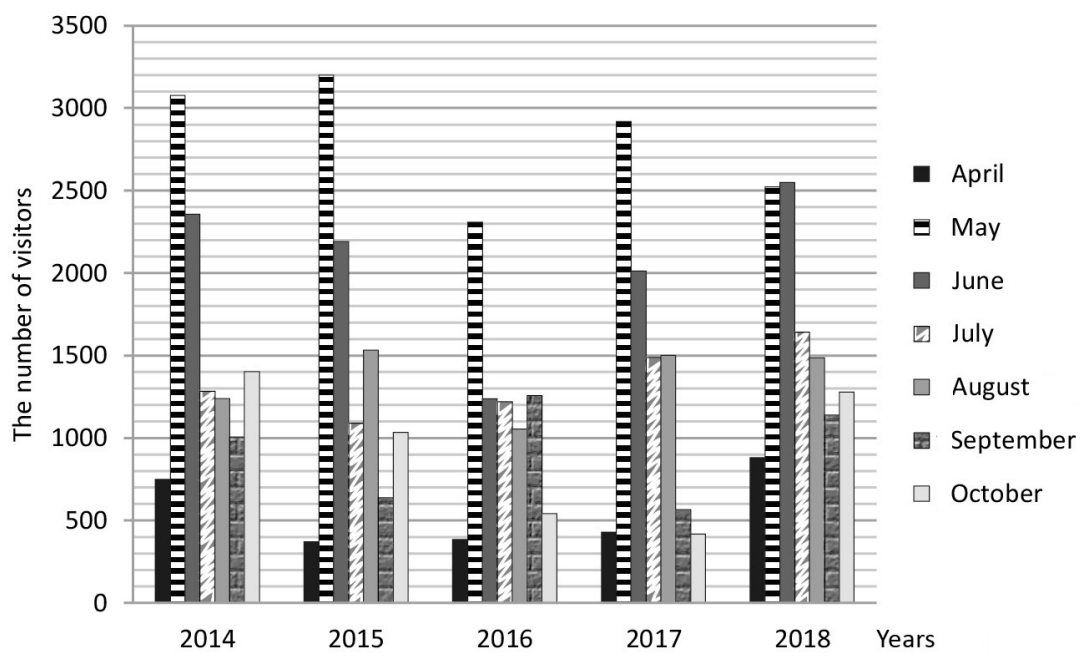

In years 2014-2017, the highest number of tourists visited the garden in May, and in 2018 - in June. During 5 years, the Arboretum was visited in May by jointly 14,030 , which stands for $28.1 \%$ of general number of visitors in this period. Second, in terms of frequency, the month was June ( $20.7 \%$ of visitors). The least people came to the Arboretum in April (5.6\%), however, only half of the month was analysed, because the Garden is opened from the mid of April (Fig. 2).

Data on frequency of both age groups: adults and children in particular months and years was presented in Table 1. Noticeable is, that frequency among visitors of the Arboretum was the highest in May, both in case of adults and children. An age group that most often visited the Arboretum were children, who visited the Garden most frequently in May and June.

In autumn period (September-October), noted was significantly less visitors from adults' group and children in relation to the remaining seasons. However, the number of children per 1 adult was definitely the highest in autumn (especially in 2015).

In 2017 , adults constituted $36.0 \%$ of all visitors. Among children, the highest number of visits was noted in May 2015 ,which constituted $32.9 \%$ of annual traffic. Most of the children (from kindergarten to high-school) visited the Arboretum in May, and mostly also in June and October as a lesson or out-of-school trips.

Organized groups, visiting the Arboretum are mainly school trips from: kindergartens, primary schools, high -schools and higher-education schools. Those groups are focused mainly on nature and forest education and use for this purposea guide who is an employee of the Forest District. Guide, showing around the Arboretum, presents collections of plants but also nature-related issues and aspects connec-
Figure 2. The number of visitors to the Arboretum in the period April - October in 2014-2018

Source: own elaboration based on data from Kudypy Forest District 
Table 1. The volume and structure of tourist traffic in the Arboretum from 15 April to the end of October in 2014-2018

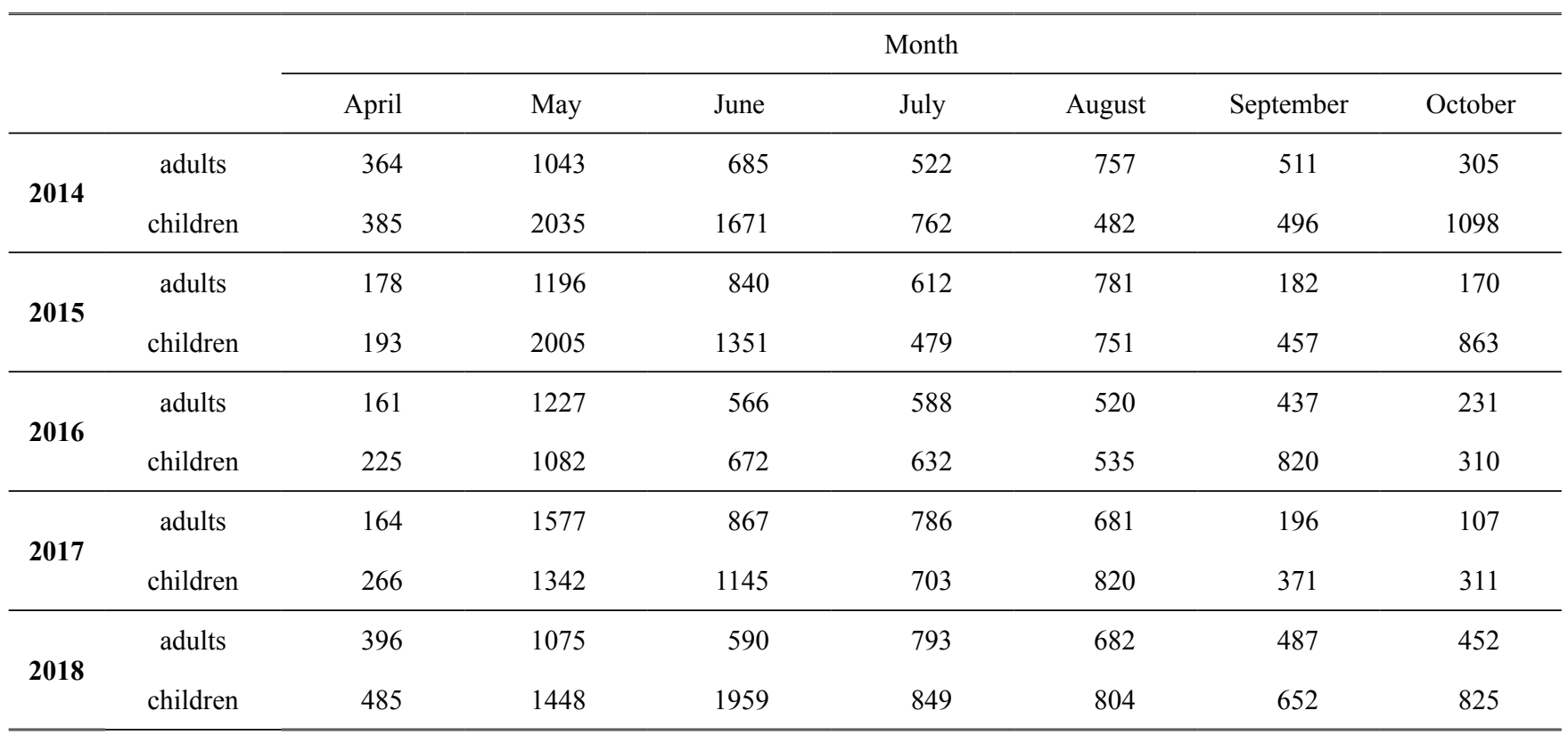

Source: own elaboration based data from Kudypy Forest District

ted with forest economy. Kudypy Forest District also offers a possibility of using mobile guide - an application for a smartphone that presents, among other things, information on the Arboretum and plants inside of it, but also map of the Garden with location of the visitor. Groups coming to the Arboretum are diverse in terms of their size, from several to several dozen people (Fig. 3).

In the years of when analysis was carried out, the frequency of organized groups was the highest in 2014, exceeding the number of 140 groups. Then a drop occurred - in 2017, the number of groups was on the level of $30 \%$ of the initial number of groups in the examined period. Last year, the number of groups slightly increased.

\subsection{Frequency during May weekend}

May weekends are characterized with high frequency of visits (Fig. 4). For needs of this elaboration, their length was set on period from $1^{\text {st }}$ to $3^{\text {rd }}$ May. Not included were the so called long May weekends, extended by public holidays, thatfall after or before them. Long May weekends in particular years of research had different length, that is, in years 2014 and 2016 - 4 days, in 2017 - 5 days, and in $2018-6$ days. However, due to May weekend in 2015, which was not extended (i.e., lasted 3 days), to standardize the results used for analysis was frequency from $1^{\text {st }}$ to $3^{\text {rd }}$ May.
At the beginning of the examined period, the frequency in May weekend was at the level of around 550 persons. In the following year,a dropoccurred, then the number of visitors started to increase and in the last year of analysis, it reached the highest level. It may have been caused by many factors, such as, weather, planned trip for May weekend or a decision to stay at home. Such trend might have been related to the length of long weekends. Length of May weekends in the following years probably were translated into higher number of tourists, visiting this area for May weekends, but also into higher touristic and recreation activity of local community (including Olsztyn residents, but also other localities)

\subsection{The use of Student'st-test of significance}

To examine the dependence between seasons and number of visitors to the Arboretum, descriptive statistics was used. In order to examine the significance for two means, Student's t-test was used. Data from Table 2 were compared and 9 possible combinations were set up (v1:v2, v1:v3, v2:v3, v4:v5, v4:v6, v5:v6, v7:v8, v7:v9, v8:v9). Calculation was made with the use of Gretl program. To each set of two means, hypotheses $\mathrm{H}_{0}$ and $\mathrm{H}_{1}$ were made. Respectively, $\mathrm{m}_{1}$ stood for mean out of $\mathrm{v} 1, \mathrm{v} 2, \mathrm{v} 4, \mathrm{v} 5, \mathrm{v} 7, \mathrm{v} 8$ and $\mathrm{m}_{2}$ stood for mean out of z v2, v3, v5, v6, v8, v9. 


$$
\begin{aligned}
& \mathrm{H}_{0}: \mathrm{m}_{1}=\mathrm{m}_{2} \\
& \mathrm{H}_{1}: \mathrm{m}_{1} \neq \mathrm{m}_{2}
\end{aligned}
$$

In the table, total number of guests were placed depending on the season and age group, and then calculations were made for comparing means on the basis of the two trials. Obtained results showed significant differences in case of v1:v2 [0.000], v1:v3 [0.000], v2:v3 [0.000], v4:v5 [0.002], v4:v6 [0.001], v7:v8 [0.000], v7:v9 [0.000], v8:v9 [0.025]. Lack of significant differences in means occurred in the case of means v5:v6 [0.528].

Results of significance test:

- $\mathrm{v} 1: \mathrm{v} 2$ at $\mathrm{t}(8)=(2185.8-1344.4) / 132.621=6.34442$ $[0.000]$;

- $\mathrm{v} 1: \mathrm{v} 3$ at $\mathrm{t}(8)=(2185.8-615.6) / 169.093=9.286$ [0.000];

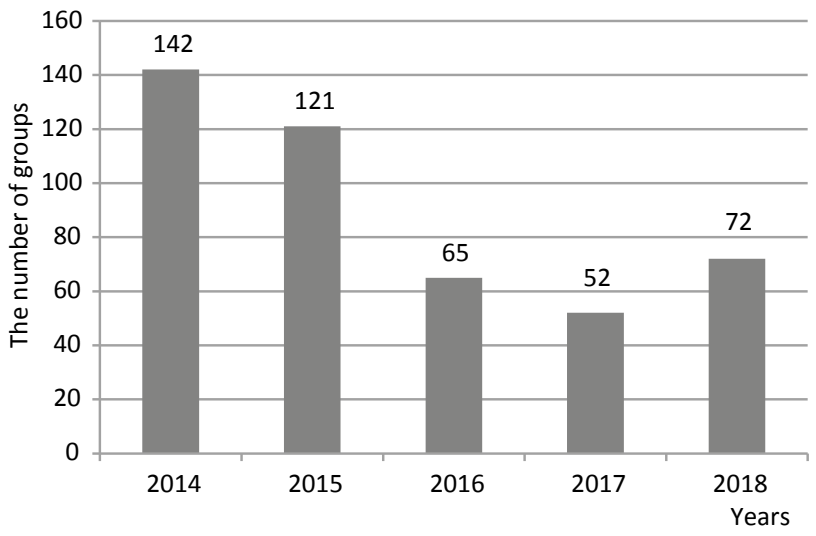

Figure 3. Group attendance at the Arboretum from April to October in 2014-2018

Source: own elaboration based data from Kudypy Forest District
- $\quad \mathrm{v} 2: \mathrm{v} 3$ at $\mathrm{t}(8)=(1344.4-615.6) / 143.057=5.09446$ [0.000];

- $\quad$ v4:v5at $\mathrm{t}(8)=(3252.8-1363.4) / 403.189=4.68614$ [0.002];

- $\quad$ v4:v6at $\mathrm{t}(8)=(3252.8-1240.6) / 423.238=4.7543$ [0.001];

- v7:v8at $\mathrm{t}(8)=(5438.6-2707.8) / 429.051=6.36475$ [0.000];

- v7:v9at $\mathrm{t}(8)=(5438.6-1856.2) / 480.271=7.45912$ [0.000];

- $\quad$ 88:v9at $\mathrm{t}(8)=(2707.8-1856.2) / 308.321=2.76205$ $[0.025]$

at the confidence level $\alpha=0.05$ indicates on rejecting $\mathrm{H}_{0}$ in favour of $\mathrm{H}_{1}$, proving significant difference in average number of visitors among the compared number of persons and age categories and seasons. Only in case of v5:v6, it was observed that there is no significant difference in means among children

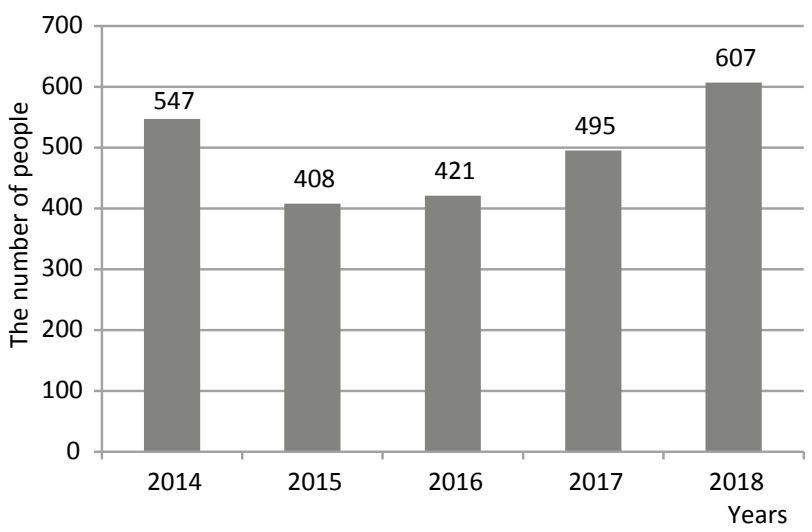

Figure 4. Attendance at the Arboretum during the May weekend (May 1-3) in 2014-2018

Source: own elaboration based data from Kudypy Forest District

\begin{tabular}{|c|c|c|c|c|c|c|c|c|c|}
\hline & Spring & Summer & Autumn & Spring & Summer & Autumn & Spring & Summer & Autumn \\
\hline 2014 & 2092 & 1279 & 816 & 4091 & 1244 & 1594 & 6183 & 2523 & 2410 \\
\hline 2015 & 2214 & 1393 & 352 & 3549 & 1230 & 1320 & 5763 & 2623 & 1672 \\
\hline 2017 & 2608 & 1467 & 303 & 2753 & 1523 & 682 & 5361 & 2990 & 985 \\
\hline 2018 & 2061 & 1475 & 939 & 3892 & 1653 & 1477 & 5953 & 3128 & 2416 \\
\hline
\end{tabular}

Table 2. The number of visitors to the Arboretum in specific seasons of the year in 2014-2018

Source: own elaboration based data from Kudypy Forest District 
visiting the Arboretum during summer and autumn. Descriptive statistics indicates, that $\mathrm{t}(8)=(1363.4-1240.6) / 185.918$ $=0.660505$, therefore, there are no grounds for rejecting hypothesis $\mathrm{H}_{0}(p=0.660505>0.05)$ in favour of $\mathrm{H}_{1}$.

\subsection{Dependence between the number of people visiting the Arboretum and seasons with the use of chi-square independence test}

Chi-square independence test is used for evaluation of stochastic significance evaluation of two variables (quantitative, qualitative, or quantitative and qualitative). In order to examine the dependence between seasons and number of adults and children visiting the Arboretum $p=0.05$, the following hypotheses were made:

$\mathrm{H}_{0}$ : variables $\mathrm{X}$ and $\mathrm{Y}$ are independent,

$\mathrm{H}_{1}$ : variables $\mathrm{X}$ and $\mathrm{Y}$ are dependent,

where:

$\mathrm{X}$ - season of the year,

$\mathrm{Y}$ - age group (adults, children).

For statistics calculation, the following formulas were used:

$$
\text { chi-square: } \varkappa^{2}=\sum_{i=1}^{r} \sum_{j=1}^{k} \frac{(n i j-\hat{n} i j)^{2}}{\hat{n} i j}
$$

theoretical frequencies: $\hat{n} i j=\frac{n_{i \cdot} n_{\cdot j}}{n}$.

For calculation of degree of freedom, the formula

$$
D=(r-1)(k-1)
$$

was used, where:

$r$ - number of rows

$k$ - number of columns,

where: $D=(3-1)(2-1)=2$.

In table below,presented is data needed for calculating theoretical values. Data was obtained by summing up the number of visitors to the Arboretum among adults and children in years 2014-2018 in particular seasons of year.

Theoretical data needed for calculating chi-square statistics were calculated on the basis of formula

$$
\hat{n} i j=\frac{n_{i \bullet} n_{\cdot j}}{n} .
$$

and amounted to $\widehat{n_{11}}=11270,74 ; \widehat{n_{12}}=15922,26 ; \widehat{n_{21}}=5611,54$; $\widehat{n_{22}}=7927,46 ; \widehat{n_{31}}=3846,717 ; \widehat{n_{32}}=5434,283$.

The results of the test indicate rejecting $\mathrm{H}_{0}$ in favour of $\mathrm{H}_{1}$. Chi-square coefficient amounted 655.35 [0.000], which means that dependence between seasons (spring, summer, autumn) and the number of adults and children visiting the Arboretum is significant. To examine the strength of this re- lationship, V-Cramer's coefficient was used. This coefficient was calculated from the formula:

$$
v=\sqrt{\frac{\varkappa^{2}}{n \min (r-1)(k-1)}}, \text { gdzie } v=\sqrt{\frac{655,35}{50013^{*} 1}} \approx 0,1145
$$

gdzie $\approx 0,1145$

$v<0.3$-weak relationship,

$0.3<v<0.5$-moderate relationship,

$v>0.5$-strong relationship (Zeliaś et al. 2002).

The value of V-Cramer's coefficient indicates a weak stochastic dependence between the examined variables, however, chi-square value shows significant dependence between seasons and number of people visiting the botanical garden.

\section{Summary and conclusion}

Polish forests are quite slightly deformed nature formation, which is an important factor of ecological balance. Forests, being a public good, in a significant way shape the quality of people's life and create favourable conditions for rest and organism's regeneration (Muszyński, Kozioł 2013; Milewski 2017). Influence on this has many components that are a part of this unique ecosystem. A peace in combination with specific climate of forests, makes it a convenient place for rest. Clear air in combination with essential oils favour maintaining or even renewal of both physical and psychical health (Marszałek 2010; Pietrzak-Zawadka Zawadka 2015; Jalinik 2016). For the sake of those, but also culture-forming and recreational aspects, forest areas decide of tourist potential of majority of voivodeships(Ministerstwo 2008; Janeczko 2015).

Obtained results indicate that the Arboretum in Kudypy is popular among different age groups. For 5 years (2014-

Table 3. The number of visitors in specific seasons in 2014-2018

\begin{tabular}{cccc}
\hline & Adults & Children & $\boldsymbol{n}_{\boldsymbol{i}^{*}}$ \\
\hline Spring & 10929 & 16264 & 27193 \\
\hline Summer & 6722 & 6817 & 13539 \\
\hline Autumn & 3078 & 6203 & 9281 \\
\hline $\boldsymbol{n}_{\mathbf{j}^{* *}}$ & 20729 & 29284 & 50013 \\
\hline
\end{tabular}

* $\boldsymbol{n}_{\boldsymbol{i} \text {. }}$ - sum of adults and children at a given time of year, sum needed for calculations nij (number of occurrences in the sample of data pairs)

$* * \boldsymbol{n}_{\cdot j}$ - total sum of adults or children, sum needed to calculate $n_{i j}$ (number of occurrences in the sample of observation pairs)

Source: own elaboration based data from Kudypy Forest District 
2018), the Arboretum was visited by 50,013 persons, however, the highest frequency was noted in 2018 (11.5 thousand persons, which stood for $23 \%$ of total number of visitors in evaluated period). Most often, they were single visitors or family groups - parents plus 1-2 children. In springtime, large frequency may be caused by holiday season (in 2014 and 2017) and the May weekend. Certainly, influence on such large number of visitors at this time had flowering of many plants. May and June are months in which in Arboretum, among others, magnolias (Magnolia spp.) and azaleas (Rhododendron spp.) bloom. At this time of the year, the garden presents many colours, which attracts guests in different age. On the other hand, for a drop in frequency during vacations may have an influence on holiday trips. During this time, the garden in Kudypy is visited in great number by people coming for holiday vacation to Warmia and Mazury. In autumn, with the start of school, large school groups come to Kudypy, which increases the number of visitors during this period.

Presented analysis indicated that the Arboretum, due to its qualities and localization, is willingly chosen for rest and recreation combined with natural education. Despite fluctuation and drops in frequency, the Arboretum is very popular. Considering, that it is available for people for around 10 days per year, average daily volume of touristic and recreational traffic amounted 55 persons. Student's t-test and chi-square test show significant dependence between the number and age of guests visiting the Arboretum and the seasons. However, with the use of V-Cramer's coefficient, it was proved that there was a weak stochastic dependence $(<0.3)$ between seasons and visitors to the Arboretum in Kudypy.

A drop in frequency in 2016 might have been related partly with opening of expanded, and modern Ukiel sports and recreation centre, located by the Ukiel Lake. The closeness of new complex may have changed the direction of tourist traffic from Olsztyn Agglomeration and its surroundings. Frequency in the Arboretum, although in 2016 was on relatively low level, started to rise again.

For intensity of the traffic, weather conditions have undoubted influence. It is visible especially in the frequency after 2018, where the number of warm, rainless days favours outdoor rest. A very significant aspect of tourist and recreation infrastructure sharing in Kudypy Forest District is its adaptation for the needs of disabled persons, which also raises popularity of this area.

\section{Conflict of interest}

The author declares lack of potential conflicts.

\section{Acknowlegdements and source of funding}

The research was financed from author's own resources.

\section{References}

Apanowicz J. 2002. Metodologia ogólna. Wydawnictwo Diecezji Pelplińskiej „Bernardinum", Gdynia, 154 s. ISBN 83-910869-9-3.

Auguścik Ł. 2017. Niszczyca anyżkowa (Gloeophyllum odoratum). Natura - Przyroda Warmii i Mazur 1(45): 12-14.

Chojecka A. 2014. Znaczenie terenów zielonych w przestrzeni publicznej oraz ich wpływ na jakość życia miejskiego. Rynek - Spoleczeństwo - Kultura 1(9): 48-54. DOI 10.18778/1733-3180.23.03.

Hołdyński Cz., Pisarek W., Kuszewska K.1999. Koncepcja programowa arboretum - ogrodu botanicznego „Kudypy”.Uniwersytet Warmińsko-Mazurski w Olsztynie, Katedra Botaniki i Ochrony Przyrody. Rkps.

Jalinik M. 2016. Obszary leśne w rozwoju turystyki. Ekonomia $i$ Środowisko 3(58): 313-323.

Janeczko E. 2015. Las i gospodarka leśna w rozwoju turystyki i rekreacji, w: Współdziałanie. Las i gospodarka leśna jako międzysektorowe instrumenty rozwoju (red. S. Zając, K. Rykowski). Instytut Badawczy Leśnictwa. Sękocin Stary, 158-167. ISBN 978-83-62830-50-3.

Janusz A., Pochopień J. 2012. Funkcje lasu w świetle preferencji konsumentów. Zeszyty Naukowe Wyższej Szkoły Humanitas. Zarzadzanie 2: 62-73.

Kuszewska K., Rutkowska P. 2018. 30 lat Leśnego Arboretum Warmii i Mazur w Kudypach - przewodnik po ogrodzie. Wydawnictwo Mantis, Olsztyn.

Marszałek E. 2010. Turystyka i rekreacja leśna. Centrum Informacyjne Lasów Państwowych, Warszawa.

Milewski W. (red.) 2017. Lasy Państwowe w liczbach 2017. Centrum Informacyjne Lasów Państwowych. Warszawa, 64 s. ISBN 978-83-65659-24-8.

Ministerstwo 2008. Kierunki Rozwoju Turystyki do 2015. Ministerstwo Sportu i Turystyki, Warszawa, $128 \mathrm{~s}$.

Muszyński Z., Kozioł L. 2013. Atrakcyjność turystyczna dóbr przyrody w lasach Polski. Zeszyty Naukowe Małopolskiej Wyższej Szkoły Ekonomicznej w Tarnowie 22(1): 87-102. DOI 10.25944/znmwse.2013.01.87102.

OECD. 2017. Hours worked. https://data.oecd.org/emp/hours-worked.htm [23.02.2019].

Pietrzak-Zawadka J., Zawadka J. 2015. Forest therapy jako forma turystyki zdrowotnej. Ekonomia i Środowisko 5(55): 199-209.

Tumiłowicz J., Hołdyński Cz., Kuszewska K., Szumarski W. 2012. Dwadzieścia lat Leśnego Arboretum w Kudypach koło Olsztyna. Rocznik Polskiego Towarzystwa Dendrologicznego 60: 69-75.

Zeliaś A., Pawełek B., Wanat S. 2002. Metody statystyczne. Zadania i sprawdziany. Polskie Wydawnictwo Ekonomiczne, Warszawa, 463 s. ISBN 83-208-1368-9. 
Żywczok A. 2015. Społeczne i wychowawcze zasoby odpoczynku. Pedagogika Społeczna 2(56): 71-86.

\section{Internet sources}

https://data.oecd.org/emp/hours-worked.htm [23.02.2019]. https://www.bdl.lasy.gov.pl/portal/mapy[22.01.2020]. www.kudypy.olsztyn.lasy.gov.pl/obiekty-edukacyjne [21.02.2019].

www.kudypy.olsztyn.lasy.gov.pl/aktualnosci/-/asset_publisher/ QyHZltR3Q604/content/historyczny-kacik-w-lesnym-arboretum [14.09.2019].

www.kudypy.olsztyn.lasy.gov.pl/aktualnosci/-/asset_publisher/ QyHZltR3Q604/content/30-lat-lesnego-arboretum[14.09.2019]. 